\title{
The Ancient Egyptian Origin of Some Architectural and Artistic Elements in Coptic Christianity
}

\author{
Rehab Mostafa Sharafeldean \\ Lecturer - Tour Guiding Department \\ Higher Institute of Tourism and Hotels, King Marriotte, Egypt.
}

\begin{abstract}
Egyptians were proud of their Pharaonic background. Thus, after their Christianization Coptic art and architecture had been affected by ancient Egyptian civilization. When Christians began to erect their churches, they adopted some architectural and artistic features from the Pharaonic Civilization. In fact, Coptic art and architecture has its own type, independent from the Egyptian, Hellenistic or other styles, however it had been influenced by these styles of the previous civilizations. When the Copts started to establish their churches some architectural elements had been adopted from ancient Egyptian temples such as the "Hypostyle Hall", which is considered the prototype of the "Basilican Plan" of the Christian church. Since the early times of Christianity Copts retained a triple division design of their churches similar to that of the ancient Egyptian temples. Dome also is the most important architectural element in Coptic Church. This architectural element most probably had been adopted from ancient Egyptian civilization.
\end{abstract}

Some other architectural elements may have been also adopted from the ancient Egyptian architecture such as Coptic apses, and altars.

Coptic art had been influenced by ancient Egyptian art as well. Ancient Egyptian common art subjects like fishing and farming had been represented frequently in Coptic art.

The objective of the paper is to introduce an overview about Coptic architecture and art, its development and its connection with ancient Egyptian civilization. The research highlights the ancient origin of the most important Coptic architectural and artistic elements in Coptic churches. A historical analysis of these elements and their functions was introduced to understand the connection between different civilizations, and how it is normal for any civilization to adopt from the previous civilizations. Descriptive method had been used in this study which was useful in describing different architectural and artistic aspects related to the topic. Analysis of the different factors that helped in this adoption, the ancient Egyptian origin of some architectural and artistic elements in Coptic 
Church, and the differences between ancient and Coptic believes which make the use of each element in Christianity serves another purpose, are also studied in the research.

Key words: Dome, Vault, Basilican Plan, Ansate Cross, Coptic Icons

\section{Introduction}

Egypt is one of the first countries on which the light of Christianity was appeared. The Egyptians were quick to embrace this new religion. Christianity was easily accepted and spread rapidly in Egypt (Habib, 1967; Malaty, 1993).

Religious and domestic Coptic architecture in Egypt does not show a break between the ancient Egyptian architecture and architecture of Coptic Period (Badawy, 1978). Some architectural elements had been inherited by early Copts from the ancient Egyptians tombs and the temples. The reason behind this adoption that from the dawn of Christianity the church was in the sheltered places from the sever Roman persecution. Thus, Copts preferred far grottoes of the ancient Egyptian rock-cut tombs and temples to practice the new religion. Hermits converted many Egyptians rock-cut tombs into chapels. They enlarged the front room of the tomb by cutting off some of its columns. A semicircular niche was cut in the middle of the rear wall of the tomb to serve as the apse of the chapel (Badawy, 1978). Several examples of these tomb chapels could be found in the Upper Egypt and Menya such as the tomb of $P 3$ Nehsy at the necropolis of Tall Al- 'Amarna. Panehsy was the first servant of the domain of Aten, the overseer of the store houses and the cattle of Aten. This tomb was used as a church by early Coptic hermits. They concealed the ancient relief of its walls and replaced them by Coptic scenes and symbols (Meinardus, 1965; Capuani, 2002). An apse shaped niche has been cut out by Copts on the north wall of the Great Hall to the left. Around the apse, Copts represented crosses with Alfa and Omega; the first and last letters of Greek alphabet symbolizing the Christ as the begging and end of life (Capuani.2002; Atiya, 1991) (Figs. 1.2). Some tombs of the cemetery of Bani Hassn also were inhabited by Christian Anchorites from the $4^{\text {th }}$ to the $6^{\text {th }}$ centuries such as the famous tomb of Nouternekht which has on its east wall some Coptic inscriptions and a Coptic alphabet (Meinardus, 1965).

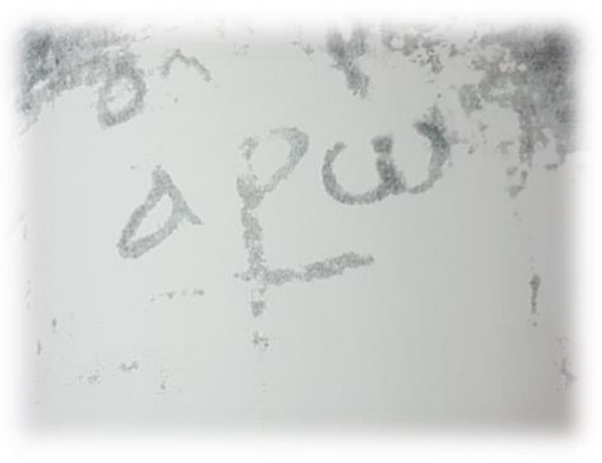

Figure 1. Cross with Alfa and Omega, Panehsy Tomb, Tall El Amarna.(researcher).

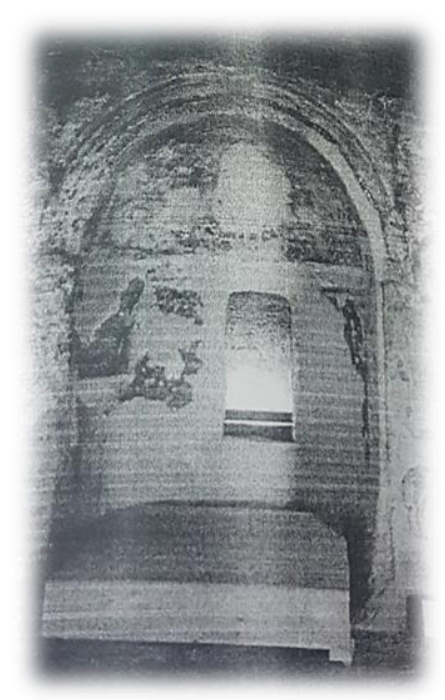

Figure 2. The Apse of the Church in the tomb of Panehsy. Tall El Amarna. (researcher).

Copts also had no hesitation to transform the most of the ancient Egyptian temples into churches. These temples were modified by early Copts and the walls had been plastered 
and painted by different Christian scenes containing saints and symbols. Several traces of these early Coptic churches still can be seen in the ancient temples of Luxor, Karnak, Madeinet Habu, and Philae (Badawy, 1978). Copts scratched Coptic Graffiti and symbols on the walls of some temples such as Edfu temple (Kurth, 2004) (Figs.3.4.5). Isna has been the home of Christian monks and anchorites from the $4^{\text {th }}$ century onwards (Meinardus, 1965; Kamil, 2002). In 1987, ruins of a church with the traditional Basilican plan opposite to Isna temple have been uncovered. This church had a moderate dimensions and dating back to the $6^{\text {th }}$ Century (James, 1988).

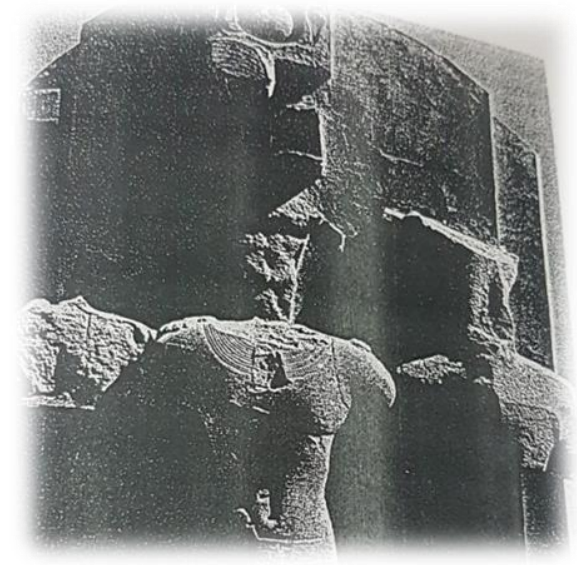

Figure 3. Remains of a statue of Thutmosis III reused by Early Copts. Karnak Temple

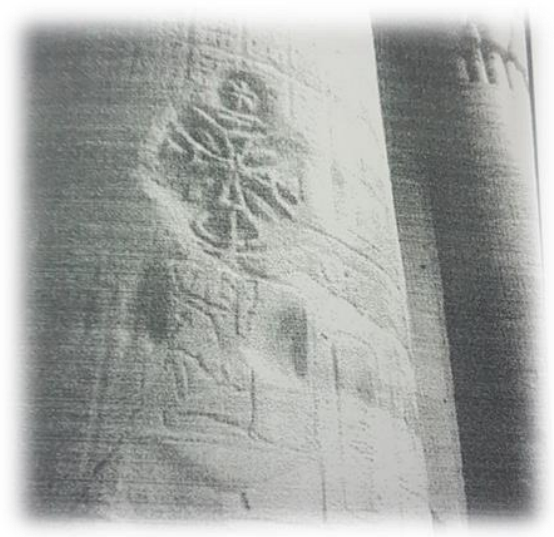

Figure.4. Coptic Cross Carved on one of the columns of Philae temple. (researcher).

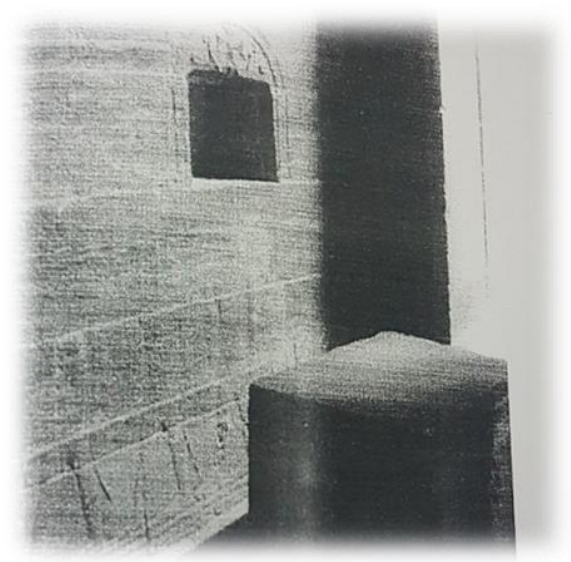

Figure 5. The Coptic Apse and Altar of the Early Church of Philae. (researcher).

In Abydos which was the holy place as by legend the head of Osiris was buried there and was an important center of the cult of Osiris (James, 1988), some sites were settled by early Copts. Part of the temple of Sety I had been converted in to a church as on the south of the corridor of kings many Greek and Coptic graffiti are scratched or painted in red (Kamil, 2002; El Zeini \& Omm Sety, 1981) (Fig. 6)

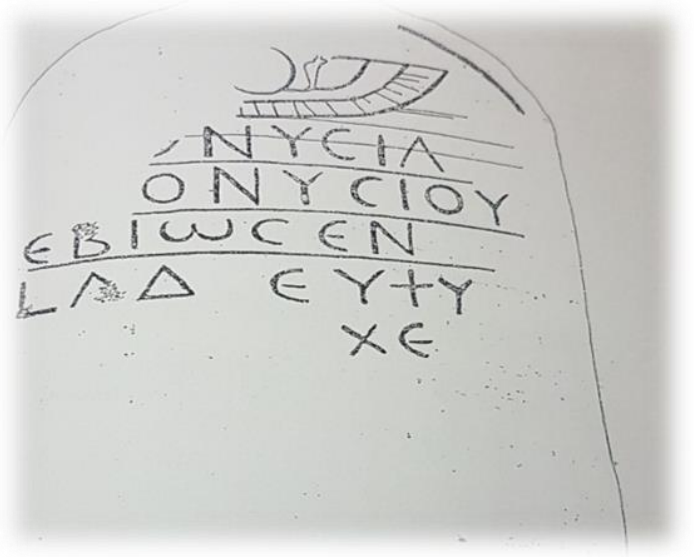

Figure 6: Stela with Coptc inscriptions, Temple of Sety I, Abydos. After: Ghazoli (1964). P.182

When Christianity became the state religion of the Roman Empire towards the close of the fourth country, many of ancient temples which were dedicated to worship different ancient deities were also converted into churches (Habib, 1967). 
Later, When the Copts started to build their own churches, it was normal for their architects to copy some of the familiar ancient Egyptian architectural elements that seemed to fulfill the requirement of the new faith during the first four centuries such as sanctuary, altar, apse, and the traditional plan of the church, which is the Basilican plan (Malaty, 2004).

\section{Early Coptic Architecture}

In the $1^{\text {st }}$ century the community of Alexandria, the Capital was divided into three groups; Egyptians, Greeks, and Jews. Christianity almost was confined among the non-Egyptians until the $4^{\text {th }}$ century. From the $4^{\text {th }}$ century Christianity started to expand between native inhabitants (Danielou \& Marrou 1964).

Before the $5^{\text {th }}$ century the concept of originality in Coptic architecture is easy to be identified and the Coptic identity is not easily to be recognizes in that early time. The reason behind this is the turning of some ancient temples into churches which prevented the development of Coptic architecture (Grossman, 1991).

Starting from the $5^{\text {th }}$ century churches were still not executed with certain identity; the stucco plaster appeared to cover the walls to hide what this building had before (El Sayed \& Kadous, 2000).

From the $5^{\text {th }}$ to the $8^{\text {th }}$ century was the most prosperous period of Coptic architecture when most of the greatest Coptic edifices were built such as the monasteries of Suhag and the Basilica of Dandara. The reason behind this prosperity was the triumph of Christianity as the official religion of the Roman Empire (Walters, 2001).

When Copts built their own religious buildings they took pride in their Pharaonic background.
Thus, when they erect their churches it was normal to copy their models and designs especially that they seemed to fulfill the requirement of the new religion (Gabra \& Van Loon, 2007).

\section{The Ancient Egyptian origin of some Coptic architectural elements}

\subsection{Dome and vault}

Dome is the most important architectural element in Coptic Church. Some churches have one dome called "Cupola". It is the who is settled in the heavens. Some churches have three Cupolas, the symbol of the "Holy trinity" (Malaty, 2004; Clarck, 1999). There are some other churches have five Cupolas. The middle one resembles the "Lord", and the four small ones around it represent the four evangelists (Malaty, 2004).

Dome is a symbol of heaven in Coptic religion (Lowrie, 1969). Copts covered their churches with both domes and vaults. Inside the church, each sanctuary was always covered with a cupola (Badawy, 1978). High temperature was also an environmental reason for using domes and vaults in Coptic architecture (Ramzy, 2012; El Suryani, 1995).

Previously, Ancient Egyptian legend used to indicate the goddess "Nut" as the dome of heaven. The relation between domes and religious buildings may have occurred due to this background (Gabra \&Van Loon, 2007)

This architectural element which is used widely in Coptic Churches and monasteries has an ancient Egyptian origin. Remains of domes dating back to the Old Kingdom are found in Seneb's tomb at Giza to the west of the pyramid of "Khufu" (Bakhshawangy, 2009; Shiha, 1988; Badawy, 1953). Tombs at Abydos and Deir al-Bahari dating back to the Pharaonic era also have some domes in their 
interior rooms. Domes also appeared in Middle Kingdom houses and inside the superstructures of Middle kingdom tombs (Badawy, 1953). Then, this architectural element has been found in the Hellenistic necropolis of Hermopolis-West in Menya which contains a number of domes (Badawy, 1953; Shiha, 1988). Afterwards, Copts adopted this architectural element to cover the early Coptic buildings such as the flat cupolas covering the earliest buildings of Deir AlAhmar in Sohag (Badawy, 1953; Bakhshawangy, 2009)

On other hand, some other historians refer the origin of the dome as architectural element to the old Iraq civilization and dating back to 5000 BC (Maher, 1971).

Butler Says that Alexandria Knew domes before Christianity and it is most probably that "Byzantium borrowed them from Alexandria than the other way around". An example of similarity between Pharaonic and Coptic architecture is given by him in the church of Gabal Al- Tair convent and a temple at the near town of Gergah in Menya province (Fig.7). In this example he identified more than seven similarities between the two buildings (Butler, 1970).

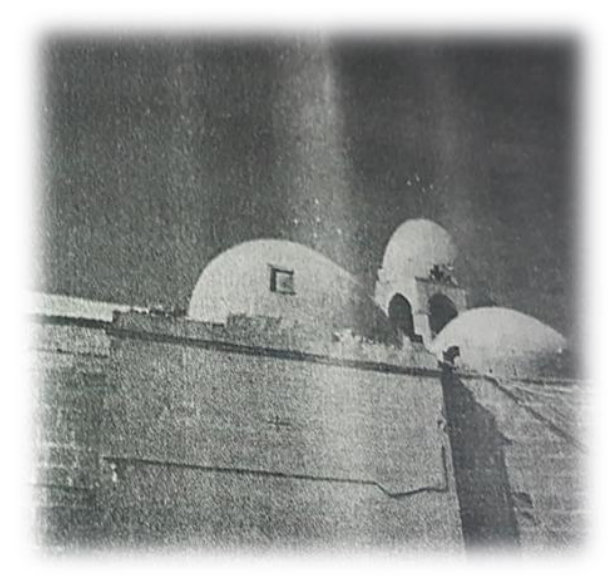

Figure 7. The Convent of Gabal Al Tai, Samalout. Menya. (Researcher)
Other of historians considered the dome is a Roman invention and the nearest Greek equivalents were the conical roofs and the corbelled vaults (Lawrence, 1983; Malaty, 2004).

From what has been mentioned above, Copts adopted this architectural element from the most ancient civilization; the ancient Egyptian architecture and has become an important element in Coptic architecture as it is impossible to find a Coptic Church lack of domes in the sanctuary or in the side rooms. The number of domes in Coptic Churches sometimes reaches to twenty domes as in the church of St. Macarius at Abu-Teig, or less in the church of Apa Bakhaumius at Edfu which has sixteen domes (Badawy.1953; Bakhshawangy, 2009). Dome was not only the favorite architectural element in Coptic churches, but also has been found in Christian tombs (Lowrie, 1969; Fakhry, 1950)

Vaults are used commonly in Coptic architecture. They are used to cover the passages, side rooms, sanctuaries, and sometimes for the entrances (Fahmy, 20092010). Vault has an ancient Egyptian origin as it was known from the Pharaonic era in the architecture of the old kingdom. The earliest example of vaults has been recorded in the $1^{\text {st }}$ dynasty necropolis at Saqqara. The burial chamber of the step pyramid of Zoser was also covered by a vault. Vaults were also found in the remains of the Ramseum in Luxor which are dating back to the time of Ramssess II $(1292-1225$ BC). In addition to vaults of the mortuary temple of Amenhotep son of Habu reaching $7.70 \mathrm{~m}$. (Spencer, 1979).

Vaults also were found in the cemetery of Bani Hassan at Menya which dating back to the Middle kingdom (Bakhshawangy, 2009).

The chapel of Tuthmosis I at Dair el-Bahari and the sanctuary in the same temple contain 
vaults (Barakat, 1999). Excavation at Giza Necropolis brought to light some flat vaults in the mastabas of "Nefri" and "S3b.f". Flat vaults in brick are known since the third dynasty as some examples are found in Beit Khallaf (Badawy, 1953). In fact, Greeks adopted vaults from ancient Egyptians. Flat brick vaults were used in Hellenistic times of Egypt such as the preserved vaults in the chapels of Hermopolis - West and Karanis (Badawy, 1953). The most ancient vaults have been of the pitched type in which each arc of bricks was laid at a slight angel to the vertical, so the weight of each new one was borne by those already in place (Beek, 1987)

Afterwards, Copts adopted this type in their buildings (Badawy, 1978, Lawrence, 1983). Smaller relieving vaults were built in Coptic buildings such as the vaults of St. Simeon's monastery at Aswan (Nicholson \& Show, 2000).

Cross vaults and domical vaults are created by the intersection of two flat vaults at right angles were commonly used in Coptic Church buildings while flat vaults were not used in Coptic architecture (Badawy, 1953; Grossman, 1991).

\subsection{Light and Shadow}

Coptic architects also inherited the practice of using light in creating a spiritual atmosphere inside the church from the ancient Egyptians. Using domes had helped giving ambrosial impression to the building with the sun movement along the day (Grossman, 1991)

\subsection{Spatial Organization}

Since the early times of Christianity Copts retained a triple division design in their churches like that of the ancient Egyptian temples with the same hierarchy and progression from the outer courtyard or narthex to a nave for peptized Christians that is separated from the Sanctuary by the Iconostasis, and finally the sanctuary which should be hidden behind the iconostasis, where only the clergy were allowed to step inside (Gabra \& Van Loon, 2007).

The sanctuary in Coptic Church represents the heaven itself or the residence place of the god among his heavenly creatures. It is also considered as the dwelling of Christ who is sitting there on the throne with his Apostles (Malaty, 2004). The sanctuary of Coptic Church stands at the east end and usually covered with lofty dome. The central sanctuary is the principle chapel, and it is dedicated to the saint after whom the church is named and dedicated, and it includes the main altar (Habib, 1967). The sanctuary of the church contains the altar. Behind the altar lies the "tribune" which is the place for the bishop and contains his throne "Cathedra". On the top of the tribune lies the "niche".

The sanctuary was considered the most holy place in ancient Egyptian temples. It was only permitted to the Pharaoh and the high persist to get inside the sanctuary. When Christians adopted the ancient temples they may tended to be cautions not to adopt any of their pagan spirit. Instead they were inclined to modify their elements to suit their own theological and spiritual believes. Copts adopt only some architectural and artistic ancient elements in form not function. Laymen were forbidden to take part in the communion inside the sanctuary area, and sometimes they were not permitted to enter it at all. This was probably to avoid one of pagan habits of taking an oath while touching the altar. Now, the worshippers can only step into the sanctuary barefooted as it is considered a holy ground (Malaty, 2004).

The Gradual design in the levels of the Ancient Egyptians temples also adopted in Coptic churches by adding the three steps 
between the choir and the nave and the step above the choir to the sanctuary (Gabra \& Van Loon, 2007)

\subsection{Fortress Shape}

Early Coptic churches and monasteries adopted the fortress design from ancient Egyptian architecture. They were built just like ancient Egyptian temples completely secluded within brick walls that to be seen from a distance. This design gave it a grim look and solid simplicity (Ramzy, 2012)

\subsection{Coptic Altar}

The Altar symbolizes the Lord Jesus Christ's tomb and the throne of god. It is considered one of the most important architectural elements in the Coptic Church. It is stand clear in the middle of the sanctuary. It is a foursided mass of brick, stone, marble or wood. Over the altar there is a lofty wooden canopy upheld by four columns (Habib, 1967). It is a cubical table on which the Holy Sacrifice is offered (the Lord's Body and Blood). Around the altar there are four pillars that end up with a dome called "ciborium" or "canopy" (Malaty, 1993).

The altar was Called "khat" in ancient Egypt. It was a table of offerings in ancient Egyptian temples and tomb chapels (Bunson, 2002).

The bringing of offerings was the focal element in ancient Egyptian temples and tombs. Therefore, offering table was one of the most important elements in cult monuments in Ancient Egypt. Although temple offeringniche tables are very similar to those of tombs, they are often called "Altars". Earliest temples offering table dating back to the Old Kingdom in the pyramid complex of Zoser and the offering tables of the fifth dynasty solar temples. They were either monolithic or brick. During the $5^{\text {th }}$ dynasty the cults used to take place in the sanctuary, however, this had been changed in the New kingdom that they became in the open court of the temple (Redford, 2001).

From the architectural point of view, Christians most probably adopted this architectural element from ancient Egyptian monuments (Malaty, 1993, 2004). Concerning this point, it should be mentioned that in early Ptolemaic era there began a great epoch of temple building in Egypt with almost the same elements of ancient Egyptian temples. Dandara, Edfu, Kom Ombo and Philae are only few of these temples built under Ptolemaic and Roman rulers, (Erman, 1907). Butlar also says that the remote root of Coptic altar is ancient Egyptian (Butler, 1884).

In Coptic Church, the altar is used for the sacrifice of Eucharist which is a spiritual and bloodless sacrifice. The church knew the sacrificial act since the apostolic age. In Coptic Church, the gates of the heaven were opened and the cross became part of the eternal life through the altar's sacrifice. According to the Christian faith there is an inner altar situated deeply in the hearts of the believers called "the Christian faith". Therefore, the altar is also considered the soul of every man built by the lord of various living stones (Malaty, 2004).

\subsection{Coptic Apse}

The Coptic Apse is one of the most important architectural elements in Coptic Church. It is a niche centered the eastern wall of each sanctuary of the church. It is also centered the eastern wall of the cells of the monks or any religious building (Moorsel, 1991; Shiha, 1988, Abu- Bakr, 2011). It is often occupied with the icon of the lord Jesus Christ coming on the cloud carried by the Cherubim and the twenty four heavenly presbyters offering incense (Malaty, 2004; Moorsel, 1991). Some others Coptic apses are occupied with the icon 
of Virgin Mary suckling her infant; Jesus Christ (Al Sayed \& Kadous ; 2000).

Most of Coptic churches having one Apse, while some others containing three apses (Fahmy, 2009-2010). The Coptic apse was developed in the fifth century into the triconch apse in the white monastery At Sohag (441AD), and the apse in the Basilica of Dandara. This type of apse is a pure ancient Egyptian influence far from the Byzantine influence which employed later in the Church of St. John at Jerusalem (450-460 AD) (Grossman, 1991) (Fig.8).

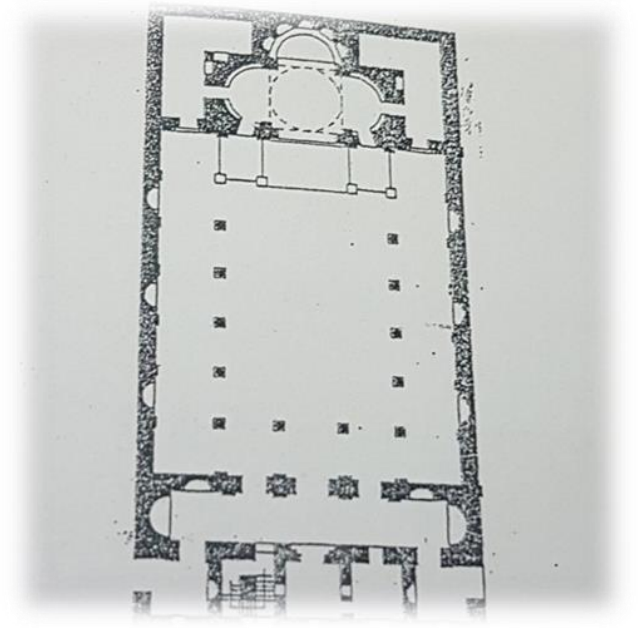

Figure 8. Tri-conch apse. After: Capuani (2002), p.24

Afterwards the fresco was replaced by the marble and dado ornaments in Coptic churches such as the Apse of the Church of St. Sergus in Old Cairo which is rebuilt in the $11^{\text {th }}$. Century and totally covered with marble (Butler, 1970).

The apses in the tombs of El Bagawat cemetery near to El Khargs city are considered the first examples of Christian apses. Afterwards the apse had been built in the early Coptic churches. Thus, Coptic apse is adopted from recesses in ancient Egyptian temples and tombs, as they are similar in the architectural form but different in the function (Bakhshawangy, 2009).

\subsection{Basilican Plan}

The Plan of Coptic church is adopted from ancient Egyptian temple which consists of three main divisions; the outer gate led into an open court which is flanked by two rows of columns, the open court is followed by the hypostyle hall (Iwentyt or wadjety in ancient Egyptian language), which is divided into a nave and two side halls, the end of the temple was the most sacred place of it "the sanctuary", or the "holy of the holies" where the deity resided and was accessible only by the high persist or pharaoh (Spencer, 1984). The primitive Coptic Church appears to have retained this triple ancient style (Fig. 9). The outer section was the narthex or the entrance of the church. Then, this outer section was followed by the central part of the church which was for worshippers. The innermost part of the church is the "Haikal" or "Sanctuary" where only the priests and deacons were admitted to officiate the mystery of the holy sacrament. Moreover, the Basilican plan of the church which began to assert itself in Coptic ecclesiastical architecture from very early times has an ancient Egyptian origin (Malaty, 2004). The remains of St. Mena's cathedral at Mariut in the western desert which is considered one of the most ancient churches had a Basilican plan. It had a central nave and two side aisles separated from the central part by two rows of marble columns. At the eastern end of that ancient church the Sanctuary was located (Habib, 1967; Malaty, 2004; Labib, 1978). 


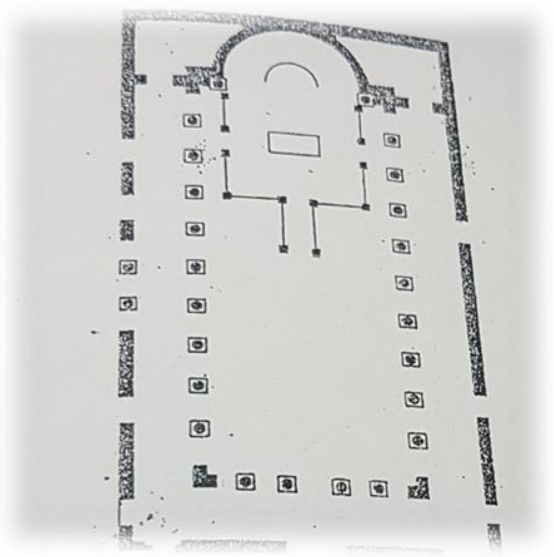

Figure 9. The Basilican Plan. After: Capuani (2002), p. 24

The Basilican plan has an ancient Egyptian origin began by Thutmosis I In his "Festival hall" in Karnak temple. This hall was divided into three parts by two rows of columns. This design appeared afterwards in the Hypostyle hall in the ancient temple of the new kingdom (Shiha, 1988; Labib, 1978).

The reason for that adoption was the conversion of same ancient temples into churches when Christian became the official religion of Egypt in the fourth country (Meinardus, 2002; Habib, 1967). The walls of those temples were plastered over and repainted with saints and Coptic scenes and crosses were cut deeply on the pillars of these temples. The altars of the temples became tables for Holy Communion (Fox, 1986; Meinardus, 2002; Habib, 1967). Concerning this point, it is should be mentioned that ancient Egyptian temples were inhabited by early Copts as refuges from the severe Roman persecution.

The Basilican plan is considered the oldest plan of the Christian churches. It consists of a nave and two side aisles. The two aisles are separated from the nave by means of columns, usually marble. The Sanctuary is on the east was either semicircular or rectangular (Capuani, 2002; Habib, 1967; Malaty, 2004;
Davies, 1952; Lowrie, 1969). The roof covering the nave in this plan is usually higher than the roof of the side aisles (Davies, 1952; Lowrie, 1969).

A pure rectangular plan was taken from ancient Egyptian architecture by Copts. The apse in Coptic churches is invariably internal. Standing outside, one sees a plain rectangular ending to the church exactly like ancient Egyptian temples unbroken with any curvature as was common in Basilican churches (Ramzy, 2012).

Some other historians return the origin of the Basilican plan to the tombs of the middle kingdom such as the plan of the tombs of Bani Hassan at Menya (Shiha, 1988).

Early Copts adopted this architectural design from ancient Egyptian temples but there were some differences between those ancient temples and the Coptic Church. The ancient temple was the "Castle of god", where the holy rituals used to be performed by the pharaoh or the high persist, and where the people had no access. On the other hand, the Coptic Church was the place of assembly for worshippers who participated in the service of the church (Badawy, 1978).

\section{Interaction between Ancient Egyptian and Coptic Art}

Ancient Egyptians believed in the religious life and in the development and progress in all aspects of knowledge, science, and art.

Copts were affected by this belief. Art has been related to religion from the beginning of history. Therefore, there had been a strong belief that art such as, painting, engraving, music, singing, and dancing have come into existence as a result of religion and religious believes (Malaty, 2004). 
Coptic artist inherited from the ancient Egyptian artist his artistic skills of engraving geometrical, floral, birds, and animal figures. $\mathrm{He}$ also inherited the wall painting and decoration. Ancient Egyptian common art subjects like fishing and farming had also been represented frequently in Coptic art (Yakoub, 1995).

\subsection{Vine Leaves and Grapes}

The columns capitals of the monastery of Apa Jeremiah at Saqqara reflect floral motifs derived from the ancient Egyptian environment (Labib, 1978). Vine leaves and grapes are the most important ornamental elements of the classical Coptic art. Copts used grapes and vine leaves motifs to decorate their buildings especially to decorate Coptic columns capitals, and the wooden screens of the sanctuaries (Shiha, 1988). As for this decorative element we can say that the Coptic art transformed the subjects of classical mythology. Vine leaves and grapes motifs were widely used in ancient Egyptian art (Labib, 1978). It has also an origin in ancient Egyptian mythology as the vine is the symbol of rebirth which symbolized the ancient Egyptian god Osiris; the god of eternity, fertility, death, and resurrection. Osiris is also called "master of the wine" in the pyramids text (Rutschowscaya, 2002; Gabra, 1996, Murray, 1992; Wilkinson, 2003; Budge, 1983). Osiris in ancient Egyptian mythology was considered the first who drink wine and the first discoverer of vine. He taught men how to plant vine and how to make it (Budge, 1983; Auths, 2000; Armour, 1986).

In the same way of Osiris, Dionysus was considered the god of wine in Ptolemaic period and his cult flourished widely from the Ptolemaic period till the first three centuries of Christian period. In Greek mythology, Dionysus is the god who discovered vine which was the symbol of rebirth (Ruschowscaya, 2002; Wilkinson, 2003; Boncenne, 1991; Martin, 1987). Thus, Dionysius was linked with Osiris, the god of eternity, fertility, death and resurrection in ancient Egypt. Dionysus was frequently depicted with dancers and musicians as significance of happy afterlife like Osiris who was also represented with musicians, singers, and dancers (Budge, 1983; Armour, 1986; Boncenne, 1991; Auths, 2000).

Wine, vine leaves, and grapes which deeply related to the ancient Egyptians art are symbols of eternity and rebirth in Coptic art (Boncenne, 1991). With the ascendancy of Christianity, the image of grape-harvesting cherubs and the vine became a frequent theme of Coptic art because of its funerary and symbolic meaning (Rustchowscaya, 2002). Grapes and vine leaves have also become the symbols of the Christ himself who says "I am the true vine, and my father is the vine grower" (John 1:15) (Rutschowscaya, 2002). Grapes and vine leaves in Coptic art are also the symbols of the sacred wine and the sacrificial blood of the Christ which is the Eucharistic blood (Barakat,1999). Basket with grapes in Coptic art is symbolizing the prophets, while the grape clusters emerging from a basket are symbolizing the state of the mankind before Christianity (Malaty, 2004). Sometimes the vine leaf refers to the holy virgin or the church itself (Abu-Bakr, 2011).

Palm leaf is also considered a very common symbol in Coptic religion which symbolizes "Victory" or the "Victory of the martyrs over death" (Labib, 1978; Abu-Bakr, 2011). Palm leaf is originally belonging to the ancient Egyptian art as it was used commonly by the ancient Egyptian artist (Labib, 1978).

The Palm Sunday in Coptic Church is the Sunday which precedes Easter. Traditional 
handicrafts using palm branches are employed with many folk songs sung while working. By this celebration, the church commemorates the entrance of the lord Jesus into inward Jerusalem to establish his Kingdom and gather all in him (Thomas, 2000; Malaty, 1993).

\subsection{Ansate Cross}

More than four hundred types of crosses are existed. Among these different types of the crosses there is the "Pharaohs cross". It is called the "Ansate Cross". It is taking the form of a sacred hieroglyphic sign "Ankh", (Fig.10) the sign of life or the key of life in ancient Egyptian language (Bourguet, 1991).

The Copts adopted this form of cross as a symbol of eternity. This cross with the Knot of the "Ankh" sign also symbolizes "Peace", and considered as a funerary symbol as sometimes was found on Coptic stelae (Bourguet, 1991).

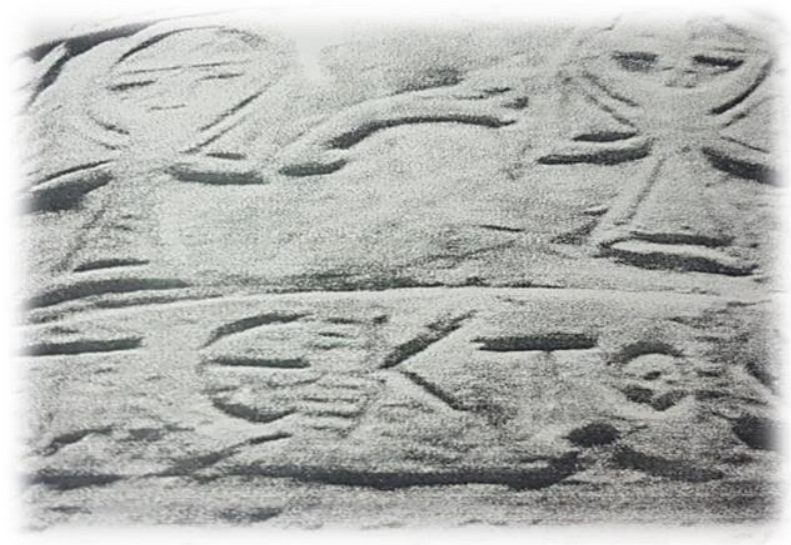

Figure 10. Limestone Stela decorated with The Egyptian "Ankh", From Edfu, 5th century, Coptic Museum

\subsection{Coptic Iconography}

Icons are flat pictures, usually painted in egg tempera on wood, but also wrought in mosaic, ivory, and other materials, to represent the Lord, the heavenly creatures and saints (Malaty, 1993).
The Coptic Iconography was also influenced by Ancient Egyptian subjects. There is a common opinion that the Coptic icon originated in Egypt before Christianity; that the earliest Coptic icons found in St. Catharine monastery in Sinai. It is suggested that they were derived from the idea of the portraits of the dead on mummy cases (George, 1973). The ancient Egyptian subjects appeared on some Coptic icon such as;

\section{The Icon of Christ the Triumphant}

The adaption of the ancient Egyptian art appeared on some themes that were represented through the Coptic icons. The icon of Christ the triumphant, of the representation of Christ trampling underfoot the lion, the dragon, the asp, and the basilisk, is known in early France art as quoted from Egypt. The reason for this that in the first times Egypt attracted many church leaders from the east and west to study in Alexandria theological school. On the other hand Alexandrian teachers and monks also preached into many countries. Through this openness of the Alexandrian church, both Coptic and Pharaonic art spread indirectly throughout the whole world (Malaty, 2004).

\section{Iconographic representation of Maria Lactans}

The Maria Lactans, echoed the Egyptian Goddess of motherhood Isis suckling her son Horus, or goddess Hathor feeding the divine pharaoh Sethos I (Meinardus, 2002).

\section{Representation of the Flight of the Holy Family}

In the well known representation of the flight of the holy family from Beit Lahem to Upper Egypt, the ancient Egyptian god of the stars and the sky (Horus) in the form of a bird whose wings touch the limits of the earth have been added. He is represented in this Coptic 
scene guides the holy family and Salome the midwife during the journey to Upper Egypt (Meinardus, 2002).

\section{Last Judgment or Heaven and Hell}

They were common representations in all over the world except for Egypt, where depictions were treated with jesting manner like to those in ancient Egyptian art (Gabra, 1996)

\section{The Udjat eye of Horus}

Coptic iconographers gave special attention to Udjat eye of Horus which was restored after it had been damaged by his brother Seth in the ancient myth. Copts considered Horus eye is the "never sleeping eye" of the Lord with which he guides his people through all difficulties and obstacles of their life (Meinardus, 2002).

\section{Conclusion}

Successive civilizations are adopting from each other; each civilization borrowed from the preceding one. Coptic civilization was affected by different civilizations; Ancient Egyptian, Greco- Roman, Byzantine and Islamic civilizations. Thus, art and architecture of any civilization should start from the previous civilization of other nations.

Throughout this study it has been shown the interplay between Coptic and ancient Egyptian civilizations. Copts adopted from ancient Egyptian civilization some architectural and ornamental elements to fulfill the requirement of their new faith. This adaption of those ancient features is considered a natural process of cultural growth. Thus, Coptic architecture drew inspiration mainly from ancient Egyptian civilization and mainly had been affected by ancient Egyptian architecture.

This interplay gave the Coptic architecture a special identity, and made it different from the Byzantine architecture in different Christian countries in all over the world. It is notable that most of early churches were from $5^{\text {th }}$ to $7^{\text {th }}$ century were built following the architecture of ancient Egyptian temples not Byzantine architecture. The common Basilican plan of early Coptic churches had been derived from the Hypostyle hall in ancient Egyptian temples.

As thoroughly discussed in this study, it can be concluded that Coptic architecture had developed from era to another due to interaction with different cultures and civilizations.

Throughout the article it has been illustrated the influence of the ancient Egyptian art on Coptic art and its subjects as well. Although some references classify Coptic art as a branch of Byzantine art, there are some Coptic artistic elements that were firstly produced by Copts such as the idea of Coptic icon which firstly appeared on the holy Egyptian land; Sinai. Coptic artists inherited the ancient Egyptian subjects such as fishing and farming.

From this, it can be concluded that early Copts had been influenced by ancient Egyptian civilization. They were tolerant enough to adopt some architectural and artistic elements from ancient Egyptians. This adoption was in form not function of these elements. Eventually, Copts produced their own architectural and artistic identity which was different from Byzantine art and architecture.

\section{References}

- Abu-Bakr, G. (2011), Al-Fnoun Al-Qibtiya, Cairo, the Anglo Egyptian Bookshop.

- Beek, V. (1987). Arches and Vaults in the Ancient near East, Scientific American, a Division of Nature America, vol. 257.

- Armour, R. (1986), Gods and Myths of Ancient Egypt, Cairo, American University in Cairo Press. 
- $\quad$ Atiya, A., (1991), The Coptic Encyclopedia, vol.7, New York, p .2160

- Auths, S.H.(2000), "Significance of Egyptian Classical and Christian themes in Coptic Art”, In: M. Immerzeel, J. Van der Vliet,( eds.), Orientalia Lovaniensia Analecta, Coptic studies on the threshold of a new millennium, II, (pp.1144-1148), Proceedings of the seventh International congress of Coptic studies, Leiden,

- Badawy, A. (1953),"Brick Vaults and Domes in the Giza Necropolis", Excavations at Giza1949. 1950, Excavations of Faculty of Arts, Alexandria university, Cairo, Government press.

- Badawy,A. (1978), Coptic Art and Archaeology, The art of the Christian Egyptians from the late Antique to the Middle Ages, Cambridge, Mass., and London: M.I.T. Press,

- $\quad$ Bakhshawangy, (2009), Al 'Emara Al kanaesiya be Mohafazet Bani Swif wal Minya W Kedesouha Al Awael, PhD, Egypt, Sohag University.

- Barakat, H. (1999), Gamaliat al-Fnoun al- Qibtya, Cairo, Book world press.

- Boncenne, C. (1991), "Mythological Symbols in Coptic Art: Dionysus", Atiya, A. (ed.), The Coptic Encyclopedia (pp.1758-1760), vol.7.NewYork, Maxwell Macmillan International,

- Bourget, S.J. (1991), "Symbols in Coptic Art: The Cross", Atiya, A. (ed.), The Coptic Encyclopedia (pp.2164-66), New York, Maxwell Macmillan International.

- Budge, E.A. (1983), Osiris and the Egyptian Resurrection, Vol.1, New York, G. P. Putnam's sons.

- Butler, A. (1970), Ancient Coptic Churches of Egypt, Vol. (2), Oxford.

- Butler, A. (1884), Ancient Coptic Churches of Egypt, vol. II, Oxford, Clarendon Press.

- Bunson, M (2002), Encyclopedia of Ancient Egypt, Revised Edition, New York, Facts On File Inc.,

- Capuani, M. (2002),"Typology Architectural evolution of the Egyptian Church", Gabra,G. (ed.), Christian Egypt Through Two Millennia (pp.40-45), Cairo, American university of Cairo Press.

- Clarck, S. (1999), Coptic Monuments in the Nile Valley, translated by Salama, I., Cairo.

- Danielou, J. \& Marrou, H (1964), The Christian Centuries, London, Darton Longman and Todd.
- Davies, T. (1952), The Origin and Development of Early Christian Church Architecture, London, SCM Press Ltd.

- El Sayed, A. \& Kadous, E.,(2000), Al Athar wal Fnoun Al Qebtya, Alexandria, Dar Al Maarefa Al Gamiya. (In Arabic).

- $\quad$ El Zeini \& Omm Sety (1981), Abydos: Holy City of Ancient Egypt, Los Angeles.

- El Suriany, B (1995), Ancient Churches in Lower Egypt, Cairo and Sinai, vol. 25, Cairo, The Institute of Coptic Studies. (In Arabic).

- $\quad$ Erman, A. (1907), Egyptian Religion, Griffith, A. (tr.), London, Archibald constable \& co. LTD.

- Fahmy, M. (2009-2010), Al-Emara wal Fnoun AlQibtya Al-Masrya, Menya.Dar Al Bahaa.

- Fakhry, A (1950), Al Saharaa Al Masrya, Gabanet Al Bagawat Fe Al Waha Al Kharga, Cairo.

- Fox, R. (1986), Pagans and Christians, Oxford, Penguin Books.

- Gabra, G. \& Van Loon, M. (2007) The Churches of Egypt, Cairo, American University of Cairo Press.

- Gabra, G (1996), Coptic Museum and the Churches of Old Cairo, Cairo, Longman.

- George, M (1973), The Origins of Christian Art, London, Thomas and Hudson.

- Ghazoli, F. (1964), "Temples of Sety I at Abydos", In ASAE (58), p.184.

- Grossmann, P. (1991), "Architectural Elements of Churches: Vault". In Atiya, A.S. (ed.), The Coptic Encyclopedia, Vol.1, (p.224-225), New York, Macmillan.

- Grossman, p. (1990), Early Christian Architecture in the Nile Valley in Coptic Art Culture, Cairo, HIES.

- Habib, R. (1967), The Ancient Coptic Churches of Cairo, a Short Account ( $1^{\text {st }}$ edition), Cairo, The Institute of Coptic Studies.

- Hillenbrand, R.(1994), Islamic Architecture, From Function and Meaning, Edinburgh, Edinburgh University Press.

- James, T. (1988), Ancient Egypt, the Land and its Legacy, Texas, University of Texas.

- Kamil, J. (2002), Christianity in the Land of the Pharaohs, Cairo, the Coptic Orthodox Church, American University of Cairo. 
- Kurth, D., (2004), The Temple of Edfu, (tr.) Alcock, A., Cairo, American University in Cairo Press.

- $\quad$ Labib, P. (1978), Coptic Art, Egypt, Cairo. Dar Al M`aref. (in Arabic).

- Lawrence, A. (1983), Greek Architecture, New York, Penguin Books.

- Lowrie, W. (1969), Art in the Early Church, New York, Norton \& Company, Incorporated, W. W.

- Maher, S. (1971), “Athar Al Fnoun Al Tashkeilia Al Watania Al Kadima Ala Fan Al Kahira fi Al 'Asr Al Fatimi”, In International Cairo History Congress Researches, April 1969, Cairo.

- Malaty, T. (1993), Introduction to Coptic Orthodox Church, Alexandria, St. George's Coptic Orthodox Church.

- Malaty, T. (2004), Church, House of God ( $6^{\text {th }}$ edition $)$, Alexandria, St. George Church.

- Martin, L. (1987), Hellenistic Religions, An Introduction, New York, Oxford University Press.

- Meinardus, O. (2002), Coptic Saints and Pilgrimage, Cairo, American University of Cairo press.

- Meinardus, O., (1965), Christian Egypt, Ancient and Modern, Cairo, American University of Cairo Press

- Moorsel, P. (1991), "Church Architecture in

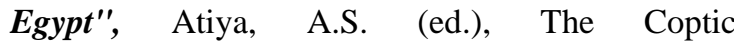
Encyclopedia, vol.2, (p. 552-555) New York, Maxwell Macmillan International..

- Murray, A.S. (1992), Who`s Who in Mythology, London, Value Proprietary.

- Nicholson, p. \& Shaw,I (2000), Ancient Egyptian Materials and Technology, Cambridge, Cambridge University Press.

- Ramzy, N. (2012), “The Impact of Local Environment Aspects on Coptic Architecture in Egypt", Alexandria Engineering Journal, Alexandria, Alexandria University. pp.325-341

- Redford, D. (2001), The Oxford Encyclopaedia of Ancient Egypt, Vol. 2, Oxford, Oxford University Press.

- Rutschowscaya, M. (2002), “The Art Using Color", Gabra, G.(ed.), Coptic Art and Monuments Through Two Millennia (p.31), Cairo, American University of Cairo Press.

- $\quad$ Shiha, M. (1988), Derasat Fel- Emara wal- Fnoun Al-Qebtya, Cairo, Egyptian Antiquities.
- Spencer, P. (1979), The Egyptian Temple: A Lexicographical study, London, Keg and Paul International PLC.

- Thomas, (2000)," The Coptic Orthodox Church and Folk Tradition", ” In: M. Immerzeel, J. Van der Vliet,( eds.), Orientalia Lovaniensia Analecta, Coptic studies on the threshold of a new millennium, II, (pp.1144-1148), Proceedings of the seventh International congress of Coptic studies, Leiden.

- Walters, C. (2001), Ancient Convents in Egypt, E. Salama (tr.), Cairo, Supreme Council of Culture.

- Wilkinson, R.H. (2003), The Complete Gods and Goddess of Ancient Egypt, Cairo, American university of Cairo Press.

- Yakoub, T (1995), The Church is God's Home, Alexandria, Nabea Al Fekr. 